\title{
INFECÇÃO MISTA DE MARACUJAZEIRO COM O Passion fruit woodiness virus E UM BEGOMOVÍRUS NO ESTADO DA BAHIA
}

\author{
QUELMO S. NOVAES ${ }^{1}$, JULIANA FREITAS-ASTUA ${ }^{2}$, ABEL R. SÃO JOSÉ ${ }^{3}$, VALDIR A. YUKI ${ }^{4}$, \\ ELLIOT W. KITAJIMA ${ }^{5} \&$ JORGE A.M. REZENDE ${ }^{1}$
}

\begin{abstract}
${ }^{1}$ Dept. Entomologia, Fitopatologia e Zoologia Agrícola, ESALQ/USP, Cx. Postal 9, CEP 13418-900 Piracicaba, SP; ${ }^{2}$ EMBRAPA/Centro APTA Citros Sylvio Moreira, Cx. Postal 4, CEP 13490-970 Cordeirópolis, SP, ${ }^{3}$ Univ. Estadual do

Sudoeste da Bahia, Cx. Postal 95, CEP 45083-900, Vitória da Conquista, BA, ${ }^{4}$ Centro de Fitossanidade, Instituto Agronômico, Cx. Postal 28, CEP 13020-902, Campinas, SP, ${ }^{5}$ NAP-Microscopia Eletrônica, ESALQ/USP, Cx. Postal 9 , CEP 13418-900 Piracicaba, SP
\end{abstract}

(Aceito para publicação em 19/09/2002)

Autor para correspondência: Jorge A.M. Rezende

\begin{abstract}
Mixed infection of passionflower with Passion fruit woodiness virus and a begomovirus in the State of Bahia, Brazil

This paper describes, for the first time, the occurrence of mixed infection of passionflower (Passiflora edulis f. flavicarpa) with Passion fruit woodiness virus and a begomovirus in the

State of Bahia. The identification of the begomovirus was based on transmission test with Bemisia tabaci, indirect ELISA, PCR and electron microscopy assays.
\end{abstract}

Entre os vírus já relatados em Passiflora edulis f. flavicarpa Deg.) no Brasil, o que causa o endurecimento dos frutos (Passion fruit woodiness virus - PWV, Potyviridae) é o mais freqüente e que maiores prejuízos causa à cultura (Gioria et al., Fitopatol Bras. 25:182, 2000; Lima et al., Caatinga 9:61. 1996). Observações recentes, em dois plantios irrigados de maracujazeiro, com seis a dez meses de idade, no município de Livramento de Nossa Senhora, Bahia, indicaram que 100\% das cerca de 10.000 plantas apresentavam sintomas de mosaico amarelo, intensa redução e encarquilhamento do limbo foliar e redução no desenvolvimento vegetativo (Figura 1A). Foram encontradas altas populações de Bemisia tabaci (Gennadius) nas plantas, com grande número de ovos, ninfas e pupas nas folhas. Aproximadamente 200 adultos de "mosca-branca" foram confinados em 20 mudas de maracujazeiro, acondicionadas em gaiola, por $48 \mathrm{~h}$. Cinco plantas mostraram sintomas de mosaico amarelo e redução do limbo foliar. Cortes ultra-finos de tecido foliar de uma dessas plantas, examinados em microscópio eletrônico de transmissão, exibiram alterações nucleares características de begomovírus e agregados de presumíveis partículas virais no núcleo do parênquima do floema (Figura 1B). Extratos de folhas de 12 plantas de campo foram submetidos a um ELISA indireto, com anti-soros contra o PWV e o Tomato yellow leaf curl virus (TYLCV) família Geminiviridae, gênero Begomovirus (Abouzid et al., Plant Disease 86:1109. 2002) e todos reagiram com ambos anti-soros. DNA total, extraído de plantas sintomáticas e assintomáticas, foi submetido a PCR, utilizando-se oligonucleotídeos iniciadores universais para os componentes A (Wyatt \& Brown, Phytopathology 86:1288,1996) e B (Rojas et al., Plant Disease 77:340. 1993) dos begomovírus bipartidos. Fragmentos com cerca de 550 e $500 \mathrm{pb}$ foram amplificados com os respectivos oligonucleotídeos (Figura 1C). Um geminivírus, tentativamente designado Passiflora leaf mottle virus, foi anteriormente encontrado em maracujazeiro em Porto Rico, em 1991 (Brown et al., Plant Disease 77:1264, 1993).

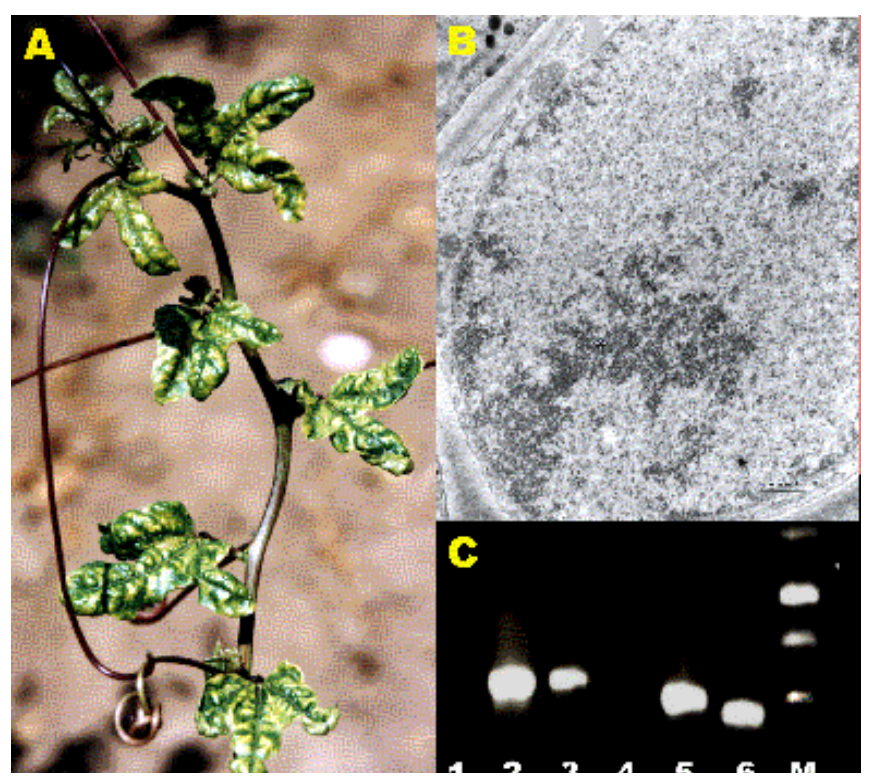

FIG. 1 - (A) Ramo de maracujazeiro (Passiflora edulis f. flavicarpa) infetado com o PWV e o begomovírus; (B) Agregados de presumíveis partículas virais no núcleo de célula do parênquima do floema de folha sintomática e (C) PCR utilizando oligonucleotídeos iniciadores A (linhas 1 - 3) e B (linhas 4 - 6) de begomovírus: 1 e 4, amostra de planta sadia; 2, 3, 5 e 6, amostras de plantas sintomáticas; M, marcador ' 1 kb DNA ladder'. 